\title{
THE EFFECTIVENESS OF ZAKAT FUNDING THROUGH DOMPET DHUAFA BEASTUDI ETOS SCHOLARSHIP PROGRAM
}

\author{
Yulya Srinovita ${ }^{1}$ \\ Purwa Udiutomo ${ }^{2}$ \\ Pedri Haryadi ${ }^{3}$
}

\begin{abstract}
The Problems of education and poverty are interrelated. The poor people cannot access higher education and they will remain poor with insufficient education. Therefore, the effort to break the cycles of poverty is to provide opportunities for the poor to obtain higher education Dompet Dhuafa through Beastudi Etos empowers education by providing coaching, mentoring and education financing funding. The population of this research is all of the beneficiaries alumni Beastudi Etos scholarship with a total sample of 190 respondents. The result of the research has shown that Beastudi Etos scholarship program is one of the programs that are quite effective in breaking the cycles of poverty through education and economic improvement. The result also indicates that the program is effective in creating excellent and independent generation. It is shown that $81.58 \%$ of respondents have successfully completed their studies (Bachelor, Master and Doctoral degrees), the others are in the process of finishing bachelor degree. $88.95 \%$ of the respondents have worked and earn income more than 7,000,000 Rupiah/month, 21.5\% have dependents from 1 up to 13 persons. In general, the respondents state that coaching and mentoring which has been given is affected on the character (97.4\%), skills (94.2\%), socials skill (97.9\%), and social generosity (97.9\%).
\end{abstract}

Keywords: Beastudi Etos, Poverty, Coaching, Mentoring, Excellent, Independent, Character, Skills, Social skills, Social generosity

JEL Classification: 122, I31

1 Supervisor of Research and Development at M akmal Pendidikan, Email: yulya.srinovita@gmail.com

2 Director of Beastudi Indonesia

3 Coordinator of Research and Development at M akmal Pendidikan 


\section{INTRODUCTION}

According to BKKBN data in 2013 (in Republika.co.id) Indonesian population about 250 million people with the number of poor people was 28.55 million (BPS, 2013). It is not much different with the World Bank states that about 31 million people are still in poverty life and 40 percent of households living just above the national poverty line, which is U.S. $\$ 21$ per month and it is still be poverty at the future. Meanwhile, the absolute number of urban poor will increase along with the urbanization in Indonesia, from 45 percent level of urbanization to be 70 percent in 2030 . Therefore this society will be important target of poverty reduction policies in Indonesia (World Bank, 2013).

This is a great homework of the nation to reduce the percentage of the poverty from year to year. One way to break the cycle of poverty is through education, because education is a basic necessity that will determine the quality of human life. The higher the educational level the greater the opportunity to improve the social welfare. Although not the only determining factor, it can not be denied that science is the key to the success of human life and knowledge gained through education. Education is also believed to be an important key to alleviate the poverty because the poverty is related to stupidity. The poverty mental, physical or material can be overcome with education even though it needs process. Therefore, the efforts to promote the social welfare can not be separated from the intellectual life of the nation.

Constitution of 1945 in Article 31, paragraph 1 states that education is the right of all citizens. Nine-year compulsory education program, in spite of all its shortcomings, strives to fulfill the basic educational rights of Indonesian citizens. However, primary education is not enough to change the fate of the poor in the midst of an increasingly tight competition of human resources. Higher education eventually becomes hope to be able to break the cycles of poverty. Unfortunately, the poor have difficulties to access to higher education, especially qualified education. Simple ways of thinking plus a variety of limited funds, the distance and information have impacted the students to be elitist groups in their eyes, only belongs to rich people. However, a student holds a strategic role in alleviating poverty, either 
directly by earning a decent income, or indirectly by criticizing public policy regarding with society. Both, vertically or horizontally by doing the community service to access the realm of policy holder in order to have a bias against people.

This problem affects the quality of human resources, according to the data of the United Nations Development Program (UNDP) in 2013 the numbers of Indonesian Human Development Index comes out to 121 of 185 countries. Although these figures show a rise of 3 ranking in 2012 which is ranked 124 of 178 countries, but Indonesia still belongs to the state HDIs in the Asia Pacific region with medium Human Development. This ranking is still lower than the ASEAN countries such as Singapore (18), Brunei (30), and M alaysia (64), and it is lower than Thailand (103) and the Philippines (114). Especially it is compared with the countries "Asian Tigers" such as Japan (10), South Korea (12) or Hong Kong (13).

The low quality of human resources is exacerbated by the depravity of the mentality of the population which is reflected in the Corruption Perceptions Index 2013 published by Transparency International. When a neighbouring country, Singapore became the 'cleanest' with Denmark and New Zealand, Indonesia stranded at number 144 of 177 countries. Meanwhile, the positions of the others ASEAN countries are higher than Indonesia, Brunei (60), M alaysia (50), Philippines (36), and Thailand (35). And not just a crime of corruption, according to the Police report, during the year 2013, there was a criminal offense in Indonesia each interval of 1 minute 72 seconds. Ironically, Indonesia HDI dropped in the field of education, whereas areas that are getting the most funding from the state budget. In State budget 2013 , there was Rp331.8 trillion or $20 \%$ of the total national expenditure budget allocated for education (setgab.go.id).

Global competition in the globalization era requires the availability of qualified human resources. Human Resource is required to have professional skills, technical and managerial creativity which is high and sensitive to a variety of changes, it can follow the control system by improving the discipline and work ethic, as well as ready to create great work with a collective work/team. According to the data from the World Economic Forum, Indonesia global competitiveness has increased to the rank 38 of 148 countries in the world, but in the 
Basic Requirement Indonesia is only rank 60 (including the fulfilment of basic education and health are only rank 62 ). It compared with the ASEAN countries; Indonesia is still on the fifth rank. Four states are higher than Indonesia are Singapore (sequence 2), Malaysia (24), Brunei (26) and Thailand (37) (Unpad.ac.id). The data of the Global Competitiveness Report 2013-2014 also mentioned that the most problematic factors for doing business in Indonesia is corruption, inefficient government bureaucracy and poor infrastructure. Indonesia is still a dark stain of bribery (rank 106) and security guarantee for the society (rank 104).

Dompet Dhuafa (DD) as the largest Lembaga Amil Zakat (LAZ) in Indonesia finds out a gap in the strategic line. Students are human resource strategic elite to manipulate the cultural and structural changes. It is said to be elite because the proportion is only $2 \%$ of the total population of Indonesia. Provision of higher education not only can improve self welfare and their family, but it can provide a positive impact on policies that favour the society. A variety of educational empowerment program has been done, one of the program that the poor potential student that is Beastudi Etos program.

The Beastudi Etos scholarship program is a scholarship program for university students who have financial limitation in 14 State Universitys (PTN) in Indonesia, namely Syiahkuala University (Unsyiah), North Sumatera University (USU), Andalas University (Unand), University of Indonesia (UI), Bogor Agricultural University (IPB), Bandung Institute of Technology (IPB), Padjadjaran University (Unpad), Diponegoro University (Undip), Gadjah Mada University (UGM), Brawijaya University (UNIBRAW), Airlangga University (UNAIR), Sepuluh November Institute of Technology (ITS), Mulawarman University (UNMUL) and Hasanuddin University (UNHAS). The funding given is the cost of going to universities, the first and second semester of tuition, dormitory accommodation for three years, an allowance of Rp450,000.00-Rp500,000.00 per month for three years, and selfdevelopment training.

The rationale to design Beastudi Etos scholarship program is because the potential of the poor are less channelled to continue their education to higher education, tuition fees are not affordable and the need for more systematic efforts to build mental and character of the 
next generation. To answer these challenges, in order to create highquality graduates, boarding coaching system has been composed and it includes strategic human resources domains which include religion, academic, social and personal development. The program is expected to establish an independent human resource and excel as an effort to break a vicious cycle of poverty. Not only providing financial funding of education and student dormitories, Beastudi Etos program also provides some services such as coaching and mentoring for the beneficiaries (commonly known as etoser) in order to get some competencies to be able to achievement.

To build the mental and character of the poor students in order to realize the vision of Beastudi Etos program which is to break the cycle of poverty and create an excellent and independent generation therefore systematic efforts are needed. Financial support is not sufficient to solve the mentality problem. Giving the opportunity to go to university is not enough without the efforts to fulfill the beneficiaries's competencies that are qualified.

To answer these challenges, in order to create graduates qualified, it is created boarding coaching system that includes strategic human resource domain that includes religious, academic, social and personal development. Because the quality graduates which will determine the extent to the cycle of poverty can be broken. The quality of graduates that will determine how sturdy self-generation is formed. Qualified graduates will be able to adapt even changing. Qualified graduates will be the solution problems of society and not adding to the problem. Quality graduates also will provide something that have quality, society transcreating can be done, not only culturally but also structurally. In order to achieve the objectives of the programs, every year, more than Rp6 billion rolled to finance coaching and boarding.

Based on consideration above, the principal problem of this research is how the effectiveness of Beastudi Etos scholarship program in breaking the devil cycles of poverty. Based on the formulation of the problem, the objectives of this research are: 1) determine the effectiveness of Beastudi Etos scholarship program to the economic beneficiaries (etoser) in breaking the cycles of poverty, and 2) determine the effectiveness of Beastudi Etos scholarship program in 
creating excellent and independent generation. By this best practice can certainly make recommendations to various stakeholders such as DIKTI, education institutions, student dormitories and managers in the selection of scholarship programs, scholarships and dormitory management and effective coaching students.

\section{LITERATURE REVIEW}

\subsection{Excellent and Independent Human Resources}

Fukuyama (1995) argued that natural resources are not everything, but the quality of the resources of human that determines the progress of a nation. This statement is the same with the condition that occurs in the people of Indonesia, which is the use of various sizes of human qualities, the Indonesia value of the nation's progress is lower than the countries of Southeast Asia, even though the wealth of Indonesian natural resources is abundant. Indonesian is a country which has many human resources, but the quality is still lower than other countries at similar stages of development.

According to Dr. Eric J. Heikkila, three important aspects of the HDI are health, education and earn. It is also published in the Guidelines in 1993, which the excellent human is aimed to be a healthy and long life (indicator: life expectancy rate); intelligent, creative, skilled, educated, devoted (indicator: level of education); independent and have access to decent life (indicator: purchasing power).

A nation can be more independent when the nation is increasingly able to realize the life that is parallel and equal with other nations with their own strengths. One of the requirements that must be met is the availability of qualified human resources which is reflected by increasing the number of professionals who are able to demand needs of development. Human resources are the important core of this development, because it is one of the inputs that determine the success of the development, as well as the output which is created by national development.

Indonesian policy makers actually have a grasp of the importance of the achievement of competence in order to establish quality human resources. Competency Based Curriculum (CBC) has 
been composed completely with the Graduates Competency Standards. Unfortunately, the application in the field does not match with the concept, students and teachers are not fully aw are about the $\mathrm{CBC}$. A nother thing to note is the unbalanced weight of competence, more predominantly on compliance aspects of knowledge that only create graduates who are intelligent, but less skilled and moreover still worse in morality. Imbalance fulfillment of competence that affects the quality of human resource has an impact to the university level which is contact directly with the working world. Moreover, it is considered that the students are iron stock and also the agent of change who played a major role determining the nation's appearance. The competent graduates will surely bring hope for the future quality of Indonesia.

Various researches show that the cumulative grade point and academic competence is not the only thing needed after graduate. For example, Paul and Murdoch (1992) in www.staff.ui.ac.id describes to face the world of work, a university graduate should be equipped with the following qualifications in order to survive and excel in competition: (1) general knowledge and mastery of the English language ; (2) communication skills include computer literacy and the Internet, audiovisual presentations, and other communication tools, (3) personal skills include self-reliance, communication skills and ability to listen, courage, spirit and ability to work in teams, initiative, and openness ; (4) flexibility and motivation to move forward is the ability to adapt according to changes in the environment as well as the time and desire to move forward as a leader.

The research of Data $\&$ Analysis Centre Tempo in 2007 states that based on the ranking, there are several factors to be considered early when the company will recruit graduates S1 Fresh Graduate, ie IPK, English language ability, regularity program research with the working position, University reputation, work experience/internship, the ability of computer applications, organizational experience and a recommendation of a particular party.

The same research also showed that the presence of ten characters that assessed in working world as an added value that is willing to work hard, has high confidence, has a vision for the future, be able to work in a team, has a mature confidence, able to think 
analytically, adaptable, able to work under pressure, proficient in English and overt behavior. Exposure above shows the importance of competence skills and attitudes, in addition to academic competence, ability to carry out a task, role or task, the ability to integrate know ledge, skills, attitudes and personal values as well as the ability to build knowledge and skills based on the experiences and lessons.

\subsection{Competencies, Knowledge, Skills and Character}

Competency concept was first applied in the United States in 1960 for teacher education programs and it continued to be developed for other professional education programs in the following years. The concept of competence is constantly evolving to Europe, Australia and all over the world so that became popular around 1993 multinational corporations. There are various definitions of competence in the literature. The word competency/competence according to William D. Powell Linguist application Version 1.0 (1997) means the skill, ability or authority.

In human resource perspective, Drs. Budiman Sanusi, M.Psi, Director of Psychology and Human Resource Development (PPSDM), said that the overall competence is the knowledge, skills, behaviours, and attitudes displayed by those successful/successful in doing a task with optimal performance (centerpoint.co.id). While the decision of the Head of the Civil Service Agency 46A No. 2003 dated 21 November 2003 determined that competence is the ability and the characteristics of a civil servant in the form of knowledge, skills and attitudes necessary behaviour in the performance of duties of office, so that the civil servants to perform their duties professionally, effectively, and efficiently. From the various definitions above, there are three main dimensions of competency, namely knowledge, technical skills and attitude behaviour (bkn.go.id).

Knowledge is the result of the idea and the conduct occurs after sensing to a particular object. Domain knowledge is very important in shaping a person's actions (overt behaviour). Experience and research has shown that behaviour based on knowledge of the behaviour will be more lasting than that is not based on knowledge. According to Notoatmodjo (2003), the elements of knowledge in human beings consists of understanding and comprehension of what it does, the 
confidence and trust of the benefits of the truth of what he did, the means necessary to do so and the drive or motivation to do that based on the needs of the felt. Notoatmodjo also adds that the knowledge has 6 levels, ie know, understanding, application, analysis, synthesis and evaluation.

Skill is the ability to apply knowledge in the form of action. Skills derived from the word skilful physical activity is caused by the presence of three elements incorporated in the learning situation. The third element is the movement, the stimulus and response that fosters coordinated motion patterns in self-learners (Sudjana, 2000, p.120).

Attitude is a material/response is still closed to a stimulus of a person or object. Attitude clearly shows the presence of an adjustment reaction to certain stimuli in everyday life is an emotional reaction to social stimuli. According Notoatmodjo (2003), attitude consists of various levels of the receiving, responding, respect (valuing) and responsible.

Competence knowledge, skills and character can be improved by training and habituation. Training is an activity to improve work ability that can help to increase understanding of the practical knowledge and application, in order to improve skills, ability, and attitudes which are necessary. The training is intended to create the human resources who have good knowledge, skills, abilities and attitudes.

There are three conditions that must be fulfilled in order an activity can be referred as an exercise, which should be able to help the trainee more functionality, should lead to a change in habits, increating, and knowledge are applied in daily activities day, and must be related to work/specific competencies. There are several benefits gained with education and training, including helping individuals to be able to make decisions and better problem solving, internalisation and operationally of motivation, achievement, responsibility and advancement, enhance self-confidence and self-development as well as helping to reduce fear in the face of new tasks (Sirait, 2006).

\subsection{Mentoring and Empowerment}

Suharto (2005) suggested that empowerment refers to the 
ability of people, particularly vulnerable and weak that they have the powers or the ability to: (a) fulfill the basic needs so that they have freedom, not only in the sense of free expression, but freedom from hunger, freedom from ignorance, freedom from pain; (b) reach the productive resources that enable them to increase their income and acquire goods and services they needed; (c) participate in the development process and the decisions that affect them.

The Empowerment targets could be either individual or collective. Ife (1995) stated that the low group that deserve empowerment are the members in groups: (1) structural low group, both low in class, gender, and ethnicity. Examples poverty category; (2) low specific group, such as the elderly, children and teenagers, people with disabilities, gay, lesbian, and isolated communities; (3) low personally group, ie they are experiencing personal problems and/or family, Cabb Sennet (Suharto, 2005) and Conway (Suharto, 2005) stated that the inability is due to several factors, among others: lack of economic security, the lack of experience in the political arena, the lack of access to increating, lack of support financial, lack of training, and physical and emotional tension. Seligman and Larner (Suharto, 2005) believe that the powerlessness experienced by a group of people is the internalization process resulting from their interaction with society. They considered themselves low and powerless, because the people think so.

According to Ife (1995) empowerment can be applied through three categories, namely: (1) empowerment through policy and planning; (2) empowerment by social and political action; (3) empowerment through education and awareness. Empowerment through policy and planning are done by developing or changing the institutional structure that allow the low group to access resources or services, thus opening up opportunities for disadvantaged groups to participate in community life.

Empowerment through social and political action is executed by establishing effective power to help the low group. Empowerment through education and awareness is emphasized by increasing the educational process so that low group were able to increase their power. The increased awareness in this case is intended to help the low groups to understand the society pressures in their environment, 
providing vocabulary and ability to work more effectively in the future.

Rappaport (Lord \& Hutchison, 1993) describe three levels of empowerment. First, the empowerment in the individual level, Empowerment in the individual level is the ability to increase personal control in living daily life and participate in their community. Second, empowerment in the small group, Empowerment in this level is characterized by the sharing of experiences, joint analysis, and influence of groups in doing business together. Third, empowerment in the community level is characterized by the use of resources and strategies to manage these resources.

The scholarship program is an empowerment. The scholarships as empowerment characterizing are: (1) the scholarship program targets are low group such as students in poor families; (2) the scholarship program aims to increase the power by providing good support costs, facilities, and coaching to target programs for university scholarships to higher education; (3) there is a process of coaching and mentoring provided in the scholarship program. The scholarship program applies empowerment to the individual level because focus on enhancing an individual's ability of beneficiariess to live and participate in the community that followed by students. The goal of empowerment scholarship program is education and awareness raising student. The effort of increasing the beneficiaries's awareness is done through coaching and mentoring. The goals, objectives, and scholarship processes characterize the process of empowerment scholarship.

\subsection{The Effectiveness of Scholarship Program}

Scholarship is the funding that given to the students or collage students to help the cost of learning. The funding of funding provided various, in general the scholarship can be grouped as follows: (1) education Scholarship, as the cost of education includes tuition fees, stationery, photocopying, and books; (2) daily life scholarship, the funding for daily life; (3) journey Scholarship is a funding for travelling, for example a trip abroad; (4) training scholarship, financial funding which is given for training itself; (5) research scholarships are used to conduct research; (6) intern Scholarship is a train skills of students in practicing the knowledge gained in school/university; (7) working 
Scholarship, scholarships are awarded to students to work part-time; (8) student exchange scholarship, common among friendly countries (Hariyanto, 2004).

Some scholarships are awarded to students S1 do not provide full funding. Some examples of the scholarships that do not provide full funding are: Academic Achievement Scholarship Development (PPA) from the government, regular scholarship from Yayasan Karya Salemba Empat, Beasiswa Djarum, dan Beastudi Etos.

Table 1.

Examples Of Scholarship And Type Of Funding Provided

\begin{tabular}{|c|c|c|c|c|}
\hline $\begin{array}{c}\text { Activity } \\
\text { Description }\end{array}$ & $\begin{array}{c}\text { PPA } \\
\text { Scholarship }\end{array}$ & $\begin{array}{c}\text { Djarum Beswan } \\
\text { Scholarship }\end{array}$ & $\begin{array}{c}\text { Karya Salemba } \\
\text { Empat Scholarship }\end{array}$ & $\begin{array}{c}\text { Beastudi } \\
\text { Etos }\end{array}$ \\
\hline $\begin{array}{c}\text { Budget } \\
\text { Source }\end{array}$ & Government & Private & NGO & NGO \\
\hline $\begin{array}{c}\text { Amount of } \\
\text { Cost Aid per } \\
\text { Month }\end{array}$ & Rp350,000 & Rp750,000 & Rp600,000 & Rp500,000 \\
\hline $\begin{array}{c}\text { Scholarship } \\
\text { Duration }\end{array}$ & 1 year and can \\
be extended & No & $\begin{array}{c}\text { Year } \\
\text { Yonitoring } \\
\text { existence }\end{array}$ & $\begin{array}{c}\text { Y year and can be } \\
\text { extended }\end{array}$ & 3 years \\
\hline $\begin{array}{c}\text { Purpose of } \\
\text { Monitoring }\end{array}$ & No & $\begin{array}{c}\text { The beneficiaries } \\
\text { become Indonesian } \\
\text { people who are } \\
\text { discipline, } \\
\text { independent and } \\
\text { have future } \\
\text { knowledge as nation } \\
\text { leader }\end{array}$ & $\begin{array}{c}\text { Yupport and } \\
\text { prepare the } \\
\text { beneficiaries to be } \\
\text { graduates who has } \\
\text { integration, has a } \\
\text { nation knowledge, } \\
\text { loyal to country. }\end{array}$ & $\begin{array}{c}\text { Yreate } \\
\text { independent } \\
\text { and excellent } \\
\text { generation }\end{array}$ \\
\hline
\end{tabular}

Coaching methods that is conducted between Djarum Beswan scholarships and Karya Salemba Empat scholarship are almost similar, through training, seminars, and workshops. Beastudi Etos coaching uses a method quite similar with Djarum Beswan scholarship and Karya Salemba Empat scholarship. The differences of Beastudi Etos is the mentoring in boarding. Mentoring in Boarding is guided by the Beastudi Etos mentoring. 
Mentoring and coaching are substantially with the empowerment paradigm which involves a beneficiaries to execute the process of learning in order to change behaviour. The changes of behaviour are expected to be the learning outcomes include changes in knowledge, attitudes, and skills. The difference between coaching and mentoring are the approach to the learning process. Coaching tends to use a top down approach. The beneficiaries attend coaching participants who got the material from the source. Mentoring is done in a bottom up approach or called participation.

The learning process the beneficiaries are done through coaching by non-formal education. Non-formal education emphasizes the effort to show the direction of change, inducing a change, and develop potential changes expected by the learners. Non-formal education to the implemented needs to notice things as follows: (1) based on the democratic atmosphere; (2) communication and interaction between students who are familiar both learning and learners with an agent of change.

The result of the research is the changes in behaviour. Shortterm behavioural changes can be seen from the increase of knowledge, mental attitude and skills. Improved knowledge, attitudes, and social skills then expected to increase the independence of the target communities.

The changes of behaviour are expected to appear to the beneficiaries are various, depending on the purpose of mentoring scholarship agencies. Prijono and Pranarka (1996) suggested that empowerment is looking at behavioural changes that occur are expected to fulfill relevant targets for empowerment. Needs of beneficiaries are able to graduate with good academic achievement. Graduation requirement is not only determined by the academic value, but also the ability to provide funds for education. The beneficiaries also need earn other than scholarships.

Rogers (2003) stated that the level of effectiveness is the ability of a program to achieve their objectives. Boyle (1981) has outlined some of the standards based on the type of program effectiveness. Effectiveness development program measured from: (1) the quality of the solution to the problems faced; and (2) the level of ability of individuals, groups or communities to develop problem solving 
abilities. The effectiveness of institutional program that are measured: (1) their competence; and (2) the assessment of the consumer or the utilize these institutions. The effectiveness informative programs are measure: (1) affordability program; and (2) how much the information is spread.

\subsection{Vision and Mission of Beastudi Etos Scholarship}

Beastudi Etos scholarship is an institution that focuses on scholarship granting to students who are excellent, but have financial limitations. Beastudi Etos is one of the programs of the education division of Dompet Dhuafa. Dompet Dhuafa is NGO that manages Zakat, Infak, Shodaqoh, and Endowments (ZISWAF).

Source of fund management Beastudi Etos comes from zakat funds which are collected by Dompet Dhuafa. Zakat is an obligatory part of the proceeds shall be issued if the charity (muzakis) has reached the limit of issuing compulsory zakat.

Beastudi Etos was established in 2003. Now, the total of beneficiaries Beastudi Etos alumni are 1,172 persons. The vision of Beastudi Etos is creating the excellent and independent self generation. The explanation of this vision is:

1. Superior means the first, be a pioneer investment program. Human resources and up date in the implementation of the program management system.

2. Creating means in an effort to provide mentoring and coaching in order to create output that corresponds to the potential per individual, not to be uniform in pattern and output but clear in planning and a discipline culture.

3. Excellent Human resources means a better value in terms of awareness, achievement and productivity religion, academic.

4. Independent human resource means human resources can be independent, not dependent on others, both financially, thoughts and attitudes, as well as pow erful and capable of empowering.

Beastudi Etos outlines vision into 4 missions are: (1) implementing quality management; (2) implementing curriculum based coaching Beastudi Etos competence; (3) establishing and 
optimizing the network Beastudi Etos; and (4) optimizing the role of Beastudi Etos human resources in empowerment community.

\section{RESEARCH METHODOLOGY}

The beneficiaries of Beastudi Etos (etoser) came from poor families and do not self confident but have a strong desire to improve themselves and their families's life. Beastudi Etos program, besides providing financial funding that includes education first year tuition and earn for 3 years, also provides boarding facilities and coaching and mentoring.

The coaching includes coaching regularly every week, management activities, social activities and the annual national coaching. Domains include domain religious, academic, social and personal development. M eanwhile, mentoring to four domains is done by regional coordinators and student dormitories companion day to day.

Etoser spreads in 14 State University (PTN) in Indonesia, namely Syiahkuala University (Unsyiah), North Sumatera University (USU), Andalas University (Unand), University of Indonesia (UI), Bogor Agricultural University (IPB), Bandung Institute of Technology (IPB), Universitas Padjadjaran (Padjadjaran University), Universitas Diponegoro (Diponegoro University), Gadjah Mada University (UGM), Brawijaya University (Unibraw), University of Airlangga (Unair), Sepuluh November Institute of Technology (ITS), University Mulawarman (Unmul) and the University of Hasanuddin (UNHAS).

The research was conducted in 2013 for 6 months using a questionnaire through Google drive facility. The population is all of the beneficiaries alumni of Beastudi Etos scholarship in academic year 2003 up to 2009, they are 815 persons. However, due to the limitation of the data from the Beastudi Etos program manager so that only 363 alumni complete the data that can be used as the research population. The sampling technique used for respondent is convenience sampling where sampling technique will select a more readily available but must consider certain criteria. The size of the minimum number of samples $(n)$ is obtained by using Slovin formula:

$$
n=\frac{N}{1+N e^{2}}
$$


where:

$N=$ number of population (363)

$e=$ error rate of $5 \%(0.05)$

Based on the formula above, the minimum number of samples in this research was 190 respondents (rounded down from 190.30). Meanwhile, the data processing techniques using Microsoft Office Excel 2010 and SPSS version 17.

\section{RESULT AND DISCUSSION}

\subsection{Respondents Identity}

According to Hurlock (1968) the adulthood is divided into three periods, namely Early Adulthood (20-40 years), Midle Age (40-60 years), and Old Age (60-die). The Etosers age who were respondents in this research ranged from 20-34 years or in early adult period. M ost of etoser are in the age range between 20-24 years are 96 persons (Figure 1). Respondents were male (98 persons) in this research more than female respondents (92 persons) although the difference is not too significant. This is because the Beastudi Etos provide equal opportunities for men and women to get the scholarship (Figure 1).
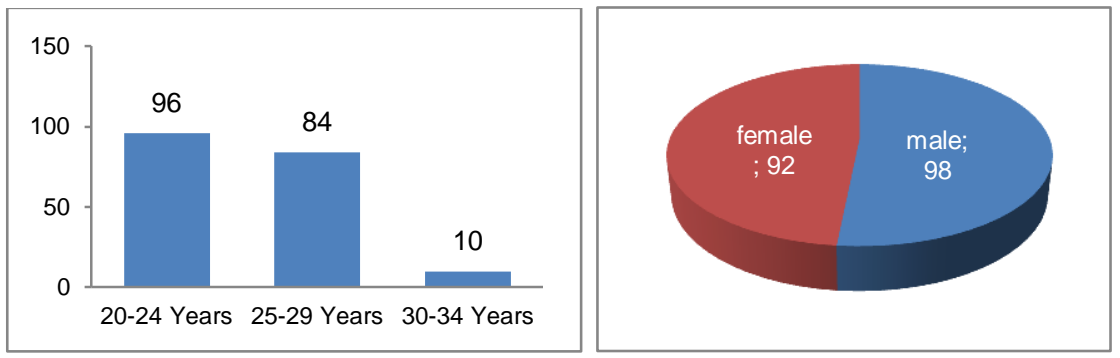

Figure 1.

Age and Sex Distribution of Respondents (Persons)

Recently, Beastudi Etos already created 815 alumni from the academic year 2003 up to 2010. The Alumni currently have spread and settled all over Indonesia and go abroad. Most of the alumni who were respondents in the research were from the academic year 2009, 
they are 52 persons. This is because the access to the younger generation still easy so that the alumni of this year still easy to be found (Figure 2).

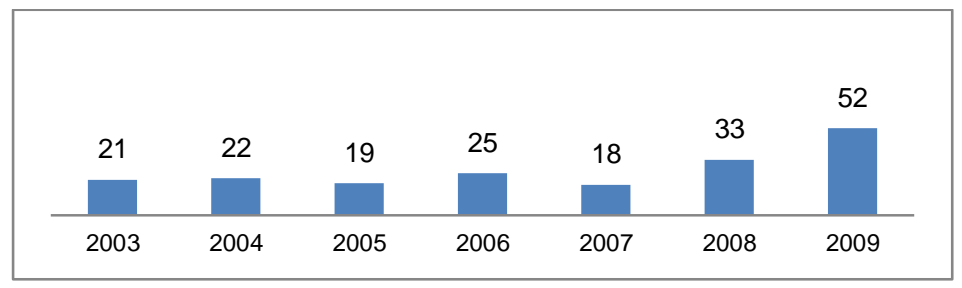

Figure 2.

Distribution of University Batch Respondents

\subsection{The Effectiveness of Beastudi Etos Scholarship Program in Breaking the Poverty Cycle Enhancement through Improvement Education of Youths as the Nation Future Generation}

One way to break the cycle of poverty is through education. According to Education M inister (2012) in situs of unhas.ac.id, Human Development Index ( $\mathrm{HDI}$ ) of Indonesian education is 0.97 , but when combined with HDI Health and IPB income per capita (as a total HDI), the percentage rise to 0.99 . This proves that the significance of the effect of education on health and income percapita is quite large (unhas.ac.id).

Beastudi Etos program is given for youth of the nation who has good achievement they are potential next generation because of the limitation economic, they do not have the opportunity to continue their education to university. It is shown from the low university enrolment rate reaching only 16.13 percent (Susenas, 2012). Beastudi Etos is presented to solve the issue by creating 816 graduated Bachelor S1 to S3. As shown in the alumni who were respondents in this research, as many as 164 persons are S1, 23 persons are S2 and 3 persons are S3. The opportunity to continue their research to gain knowledge as much as possible with incised various achievements both academic and non-academic. In the academic field indicated that most etoser continue their education to pursue S2 and S3 through scholarship programs either in country or and outside of the country, 
so there is a Etoser who became outstanding students at each campus.

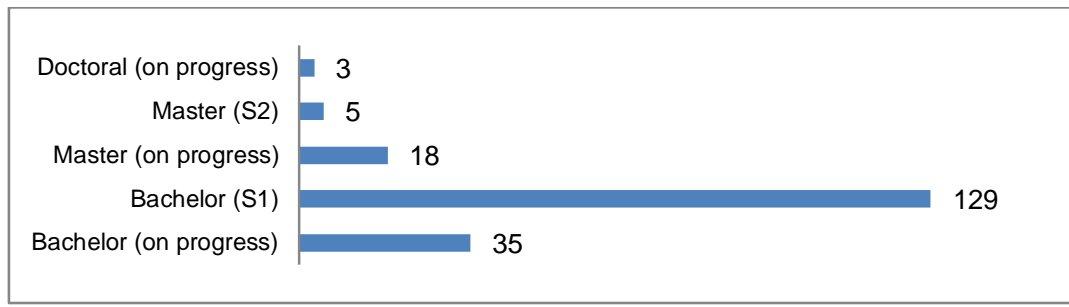

\section{Figure 3. \\ Distribution of Respondents Education}

In the non-academic, the achievement is demonstrated by most etoser winning both competitions in the field of journalism, entrepreneurship program, and research. For example, in 2006, 3 persons etoser sent to Egypt to follow the Worldwide Final Design for Development Award 2009 Cairo and succeed get a big 5. And many more accomplishments achieved by the etoser to date (Profil Beastudi Etos, 2009). Research results of M eidiyanti (2013) on the beneficiaries Beastudi Etos in 2011 and 2012 also showed that 80.5 percent of etoser have high academic achievement by high category.

\subsection{The Effectiveness Beastudi Etos scholarship Program in Breaking the Poverty Cycle Third Generation through Improvement of Economic Conditions of the Family}

If the etoser parents described as the first generation then the etoser is the second generation in a family. They are the ones who come from families with lower economic because their parents have less work and a decent income. By the funding of Beastudi Etos scholarship, they have opportunity to continue their education to the university level.

Most of the alumni who were respondents in this research have unmarried status (137 persons), 53 persons were married (Table 2). From 53 persons who are married, in Figure 4 it can be seen that most have a partner with S1 (32 persons). It means the education positively 
correlated with education of etoser itself. The higher of someone's education, so the higher education of their partner. If they have higher education their family economic life in the future will be better than their previous family economy. Thus indirectly the cycle of poverty in the third generation will be disconnected. This is proved in the research conducted by Hendra Ridho D. Siregar (2005) and Salawuddin Bainaho (2004) in Tarigan (2006) which state that there is a significant relationship between level of education and family economic conditions. It means that the effect of education level to determine a family otherwise poor or not poor.

Table 2.

Distribution of Marital Status of Respondents

\begin{tabular}{|c|c|c|c|c|c|c|c|}
\hline \multirow{2}{*}{ No } & \multirow{2}{*}{ Gender } & \multicolumn{3}{|c|}{ Marital Status (persons) } & \multicolumn{2}{c|}{ Total } \\
\cline { 3 - 8 } & & \multicolumn{2}{|c|}{ Single } & \multicolumn{2}{c|}{ Married } & \multicolumn{2}{c|}{} \\
\cline { 3 - 8 } & & $\mathrm{n}$ & $\%$ & $\mathrm{n}$ & $\%$ & $\mathrm{n}$ & $\%$ \\
\hline 1 & Men & 64 & 33.68 & 34 & 17.89 & 98 & 51.58 \\
\hline 2 & Women & 73 & 38.42 & 19 & 10.00 & 92 & 48.42 \\
\hline \multicolumn{2}{r|}{ Total } & 137 & 72.11 & 53 & 27.89 & 190 & 100.00 \\
\hline
\end{tabular}

Figure 4 also shows that the distribution of work/activity of respondent's partner. The activity of respondents' partner currently grouped into three, namely work (entrepreneur, civil servants, private sector employees, teachers, and lecturer) are 42 persons, housewives are 14 persons, and collage students are 7 persons. It means that the couples who work more than couples who do not work, so the couples have the potential to help the respondents family finances.
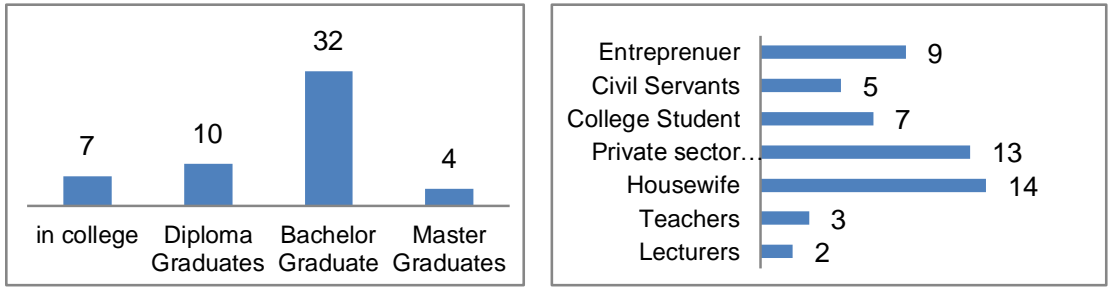

Figure 4.

Distribution of Education and Employment/Activity Couple Respondents 


\subsection{The Effectiveness of Beastudi Etos scholarship Program in Reducing Unemployment through Entrepreneurship Activities}

Economic development of a country is influenced by a number of existing entrepreneurs in the country. This is because entrepreneurship activity can reduce the unemployment rate. Deputy for Restructuring and Development of the Ministry of Cooperatives and UKM Chairul Djamhari (2013), in sindonews.com (2013), states that the number of entrepreneurs in Indonesia is only 1.26 percent. A country can develop when the number of entrepreneurs at least 2 percent. The number of entrepreneurs in Indonesia is still lower than ASEAN countries, especially Singapore and Malaysia. Based on data BPS (2013) Indonesian unemployment was recorded at $7.39 \%$. Therefore, the emergence of the field - needed new jobs to absorb the unemployed.

One of the expected outputs of the coaching Beastudi Etos scholarship program is to create young entrepreneurs who are ready to change the nation's economy and reduce unemployment. If the respondents in this research grouped by entrepreneurship activity then there are two types of activities the respondents, namely entrepreneur and non entrepreneur (Figure 5). Entrepreneur respondents are conducting entrepreneurship respondents although they also worked in other fields. They are private employees and entrepreneur (9 persons), student and entrepreneur (11 persons), civil servants and entrepreneur (4 persons), and entrepreneur (14 persons) (Table 4). M eanwhile, non-entrepreneur respondent is respondent who does not conduct entrepreneurship.

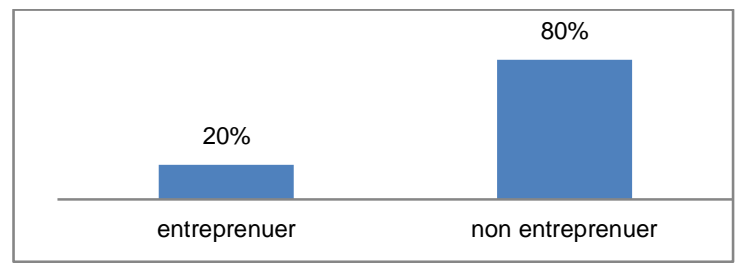

Figure 5.

Distribution of Respondents based on Type of Activity and Duration Conducting Entrepreneurship Activity 
Figure 5 show that 38 respondents $(20 \%)$ have activity as an entrepreneur. The business areas include IT companies acted, trade (fashion, food \& beverage, property, and agriculture), services (education, health, and transportation), the media, etc. The distribution of their income is between Rp1,000,000.00 up to Rp750 million per month and their employee between 1-8 persons. They have been running the businesses from 1 month up to 8 years. Most respondents (16 persons) have done entrepreneurship activity for 1 year (Table 3). In fact, one of the beneficiaries Beastudi Etos alumni 2007 get award "100 Youth, Women, Netizen most Influential in Indonesia in 2011". Various championships her managed to get both the national and the international in the field entrepreneurship. Currently, she has set up three companies and get income more than 2 billion/month (Beastudiindonesia.net).

Table 3.

The Distribution of Respondents based on duration conducting Entrepreneurships Activity

\begin{tabular}{|c|c|}
\hline $\begin{array}{c}\text { Duration of Entreprenuership } \\
\text { Activity }\end{array}$ & $\begin{array}{c}\text { Number of } \\
\text { Respondents }\end{array}$ \\
\hline $1-6$ months & 3 \\
\hline $1-3$ years & 28 \\
\hline $4-5$ years & 6 \\
\hline 8 years & 1 \\
\hline Total & 38 \\
\hline
\end{tabular}

Meanwhile, 152 respondents (80\%) are non-entrepreneurs with activities as employees of government and private enterprise, lectures, and housewives. Most of them non entrepreneur respondents $(41.05 \%)$ worked as private employees 1-8 years. Furthermore, 22 respondents $(11.58 \%)$ w wile freelance tuition for university tuition and living with an average income of Rp1,000,000.00-Rp2,000,000.00 per month. In addition, there are two respondents who work as housewives because they follow their husbands who go abroad. 
Table 4.

Distribution of Respondents by Profession

\begin{tabular}{|c|c|c|c|}
\hline \multirow{2}{*}{ No } & Type of Occupation & \multicolumn{2}{|c|}{$\begin{array}{c}\text { Number of Respondent } \\
\text { (Person) }\end{array}$} \\
\cline { 3 - 4 } & & $\mathrm{n}$ & $\%$ \\
\hline 1 & Lecture & 11 & 5.79 \\
\hline 2 & Part Time & 4 & 2.11 \\
\hline 3 & Private Employee & 78 & 41.05 \\
\hline 4 & Private Employee \&Entreprenuer & 9 & 4.74 \\
\hline 5 & College students\&Freelance & 22 & 11.58 \\
\hline 6 & College students \&Employee & 3 & 1.58 \\
\hline 7 & College students \& Civil Servant & 1 & 0.53 \\
\hline 8 & College students \& Lecture & 2 & 1.05 \\
\hline 9 & College students \& Entreprenuer & 11 & 5.79 \\
\hline 10 & Civil Servant & 10 & 5.26 \\
\hline 11 & Civil Servant \&Entreprenuer & 4 & 2.11 \\
\hline 12 & Entreprenuer & 14 & 7.37 \\
\hline 13 & Housewives & 2 & 1.05 \\
\hline 14 & College students (only focus on study) & 19 & 10.00 \\
\hline & Total & 190 & 100.00 \\
\hline
\end{tabular}

4.5 The Effectiveness of Beastudi Etos Scholarship Program in Creating Excellence and Independent Generation through Coaching and Mentoring

\subsubsection{Creating Excellence Generation who can compete in the Working world}

The beneficiaries's age of alumni Beastudi Etos scholarship ranged between 20-40 years. According to Hurlock (1968) this age is early adulthood group. In early adulthood age is to start working. In facing this development task, the men tend to notice and an early start to think about it, often ignoring other tasks, such as delaying to seek and find a wife to be a prospective spouse prior first find a job that is clear and fixed. This certainly shows the difference when compared to the early adult women who tend to have not been so active in facing of the demands of the job.

Early adulthood is called the youth time. This is term as written by a sociologist, Kenniston (Santrock, 2008) states that the youth is a transition period between adolescence and adulthood that is a time of renewal and personal economic conditions. Furthermore, Kenniston 
said two important criteria to indicate beginning of early adulthood, namely economic independence and self-reliance in making decisions. The decision is related to the completion of their study, the choice of a job, also cannot be separated from the decision in facing of readiness for marriage.

One of the coaching and mentoring programs of Beastudi Etos is to create a generation who is ready to compete in the working world. Their skill is created by mentoring either training, fulfilling leaders, or practice. Training program performs leaders who are able to increase the etoser motivation to succeed both leadership and entrepreneurship. The results of this research indicate that the majority of respondents (124 persons) stated that the coaching and mentoring program can add their stock in facing the working world, even as many as 21 respondents said it is enough. However, there are 6 respondents who answered was not enough. They say that the coaching program for etoser is still lack of knowledge to provide of jobs. For the third year should be focused on finalizing plans for the future and explore the horizons of the field that want to be reach. Not only is always gained to entrepreneurs only, although self-employment is the basic of all jobs.

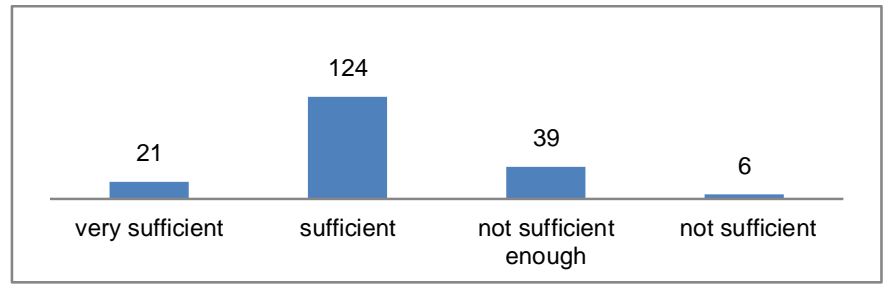

Figure 6.

Distribution of Respondents based on Perceptions of Coaching and Mentoring Programs in Adding Provisions to Face the World of Work

Psychologically, Early Adulthood group are not able enough to reach maturity. This is due to of many problems he faced and unable to solve. The issues are: (1) difficult to find the work; (2) difficult to find a mate; (3) the desire to get married but does not have income; and (4) the difficulties experienced after marriage, such as raising children, maintaining family harmony, and conflict between the need 
to use income children with the cost of everyday household (Santrock, 2008).

But different with the early adulthood group in general, the beneficiaries's alumni Beastudi Etos able to solve the problem of 'having trouble finding a job'. This is proved from the data in Table 5, which shows that the majority of respondents $(56.80 \%)$ had worked before graduation. Meanwhile, 40 respondents $(24.67 \%)$ has been getting the job less than three months after graduation, and only $2.37 \%$ of respondents who got jobs after $1-2$ years after graduation.

Table 5.

Distribution of Respondents based on Job Waiting Period

\begin{tabular}{|c|c|c|}
\hline \multirow{2}{*}{ Job W aiting Period } & \multicolumn{2}{|c|}{$\begin{array}{c}\text { Total Respondents (190) - Total } \\
\text { respondents who did not/has not } \\
\text { worked (21) }\end{array}$} \\
\cline { 2 - 3 } & $\mathbf{n}$ & $\%$ \\
\hline Has worked before graduation & 96 & 56.80 \\
\hline Less than 3 months after graduation & 40 & 23.67 \\
\hline 3-6 months after graduation & 23 & 13.61 \\
\hline 6-12 months after graduation & 6 & 3.55 \\
\hline 1-2 years after graduation & 4 & 2.37 \\
\hline Total & 169 & 100.00 \\
\hline
\end{tabular}

Consider from the developmental tasks that must be completed during this period, a person who is adults are required to complete initial development tasks, including: (a) developing the attitudes, knowledge, and practice of religion; (b) obtaining or start entering the working world; (c) selecting a partner (husband or wife); (d) starting entering the marriage; (e) learning about family life; (f) Caring for and educating children; (g) managing household; (h) acquiring skills and steadiness career (working position); (i) taking responsibility or role as citizens; and (j) looking for a fun social group (Santrock, 2008). In general, as shown in Table 6, the alumni beneficiariess Beastudi Etos has been able to accomplish the task of development points (b). Coaching and mentoring program gain a strategic stake in helping respondents to complete this task. It is based on Table 6 , which shows that the majority of respondents $(65.26 \%)$ said that the coaching and mentoring Beastudi Etos program obtained relevant with the requirements of the working world, even $22.11 \%$ of respondents 
answered very relevant. M eanwhile, only a small part of the answer is irrelevant $(2.63 \%)$ and less relevant $(10.00 \%)$.

Table 6.

Distribution of Respondents by Relevance Coaching and Mentoring Program with the World of Work Requirements

\begin{tabular}{|c|c|c|}
\hline \multirow{2}{*}{ Level of Relevance } & \multicolumn{2}{|c|}{ Number of Respondents (persons) } \\
\cline { 2 - 3 } & $\mathbf{n}$ & $\%$ \\
\hline Irrelevant & 5 & 2.63 \\
\hline Less Relevant & 19 & 10.00 \\
\hline Relevant & 124 & 65.26 \\
\hline Highly Relevant & 42 & 22.11 \\
\hline Total & 190 & 100.00 \\
\hline
\end{tabular}

There are many way how the respondent in obtaining a job is divided into three, namely (a) offered but through tests, (b) pure competence through the stages of the test, (c) a recommendation from someone/no tests. More than half of the respondents $(61.29 \%)$ get a job nowadays with pure competence through the stages of the test. Furthermore, $24.52 \%$ of the respondents worked as yet offered through the test and only $14.19 \%$ are working with a recommendation from someone/no test. It can be concluded that most of the beneficiaries Beastudi Etos can compete in the working world (Figure 7).

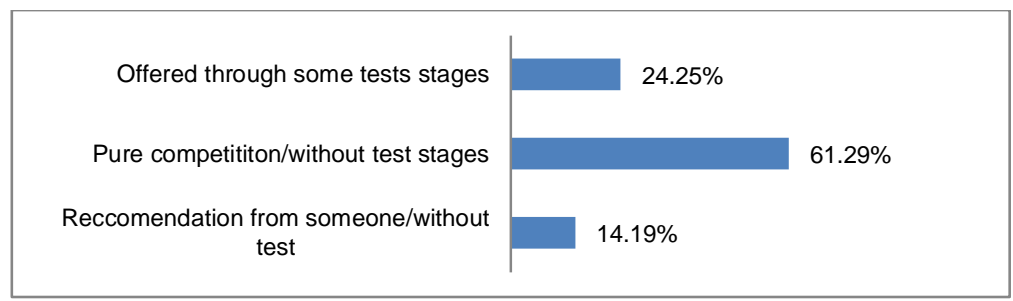

Figure 7.

Distribution of Respondents by How to gain work

Entering a work sign the beginning of the new roles and responsibilities for individuals. The demands of the role of career showed very high competence in early adulthood phase. When the people enter the working world for the first time, the tendency is faced with problem and condition that they did not previously 
anticipated. The transition is required when an individual tries to adjust to a new role. Fulfilling the demands of career and adjustment to the new role is important for individuals in early adulthood phase (Heise, 1991; Smither, 1988 in Farida, 2012). Conditions such as these require good self-control on the job and work environment so that they are able to show good performance, especially to the work partner. The result of this research indicates that $77.42 \%$ of respondents received a good assessment of the work partner. Even $20.97 \%$ got a very good judgment and only $1.61 \%$ was bad. However, the respondents are expected to maintain and improve the performance of their work better (Figure 8).

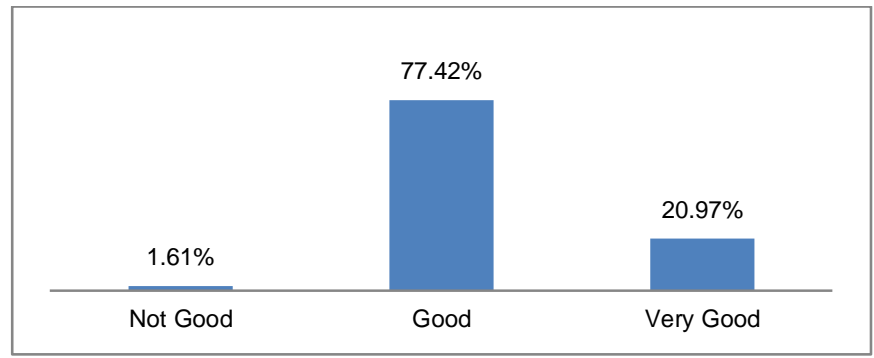

Figure 8.

Distribution of Respondents Based on Partners Assessment

\subsubsection{Creating of Excellence Generation in Knowledge, Skill and Character}

Udiutomo research result (2011), mentions that in general coaching and training program affect the increased competence of the beneficiaries Beastudi Etos in knowledge, skill, and character. Respectively, the most powerful influence is to improve the character competence, skill, basic competency. From 24 indicators that were researched, there is only one indicator lack of influence $(62.37 \%)$, which is an indicator of IT capabilities. Complete results can be seen in Table 7 below. 
Table 7. Effect of Coaching and Mentoring Per Indicators of Competence

\begin{tabular}{|c|c|c|c|}
\hline Competence & Indicators & $\begin{array}{c}\text { Average } \\
\text { Achievement }\end{array}$ & Description \\
\hline \multirow{8}{*}{ Knowledge } & Academic Plan & $74.03 \%$ & Influential \\
\hline & GPA above 3.00 & $72.41 \%$ & Influential \\
\hline & English & $63.71 \%$ & Influential \\
\hline & Scientific attitude & $73.12 \%$ & Influential \\
\hline & Reading culture & $73.54 \%$ & Influential \\
\hline & Writing culture & $65.08 \%$ & Influential \\
\hline & Academic culture & $70.42 \%$ & Influential \\
\hline & Critical thinking & $75.08 \%$ & Influential \\
\hline \multicolumn{2}{|c|}{ Average } & $70.92 \%$ & Influential \\
\hline \multirow{8}{*}{ Skill } & Self development & $74.68 \%$ & Influential \\
\hline & Managerial skill & $74.29 \%$ & Influential \\
\hline & Communication Skill & $78.16 \%$ & Influential \\
\hline & Leadership Skill & $80.24 \%$ & Influential \\
\hline & Netw orking Skill & $79.90 \%$ & Influential \\
\hline & IT Skill & $62.37 \%$ & Less Influential \\
\hline & Entrepreneurship & $71.51 \%$ & Influential \\
\hline & $\begin{array}{l}\text { Motivation to achieve } \\
\text { something }\end{array}$ & $81.05 \%$ & Influential \\
\hline \multicolumn{2}{|r|}{ Average } & $75.27 \%$ & Influential \\
\hline \multirow{8}{*}{ Character } & Gratitude Attitude & $83.25 \%$ & Very Influential \\
\hline & Feeling sufficient & $73.25 \%$ & Influential \\
\hline & Religious value & $87.24 \%$ & Very Influential \\
\hline & Islamic charity & $82.04 \%$ & Very Influential \\
\hline & Recite Qur'an & $75.62 \%$ & Influential \\
\hline & Sharing knowledge & $78.77 \%$ & Influential \\
\hline & Sikap Social attitude & $77.19 \%$ & Influential \\
\hline & Society relationship & $80.64 \%$ & Influential \\
\hline \multicolumn{2}{|c|}{ Average } & $79.77 \%$ & Influentisl \\
\hline
\end{tabular}

In general, the results of this research also showed that coaching and mentoring that had been given effect on the character, skill, social skills, and social generosity of the alumni. It can be seen in Figure 9, $185(97.4 \%)$ of respondents stated that the coaching and mentoring that they get affect their character. They become grateful human, vibrant examine the Qur'an and increasing the value of religious Islamic charity and sharing knowledge.

Meanwhile, $179(94.2 \%)$ of respondents stated that coaching and mentoring that received able to increase their skills. The skills 
acquired are Leadership skill, public speaking, writing skill, entrepreneurship skill, art skill, design, journalism, organization, committees, and time management. Central Beastudi Etos data management states that 100 percent of the beneficiaries Beastudi Etos is an active student on campus, both on campus and off-campus organizations. In addition, coaching and mentoring program are also formed BEM ETOS intended for etoser. In this program etoser can also learn abilities/skill other than obtained in their organizations.

Same with the ability to socialize and charitable soul, 186 $(97.9 \%$ ) of respondents said that coaching and mentoring of Beastudi Etos program that they got in improving their ability to socialize with people and also add to the generosity of their social life. This is because, during coaching and mentoring etoser were given the assignment to interact with the local community to implement social service program in their environment for 1 week, the environmental clean-up program with the campus community, Expo Ethos program, Ethos program outreach programs to schools, volunteer disaster response, productive village, free lesson course, health services, management of places of worship, stocking animal sacrifices, etc.

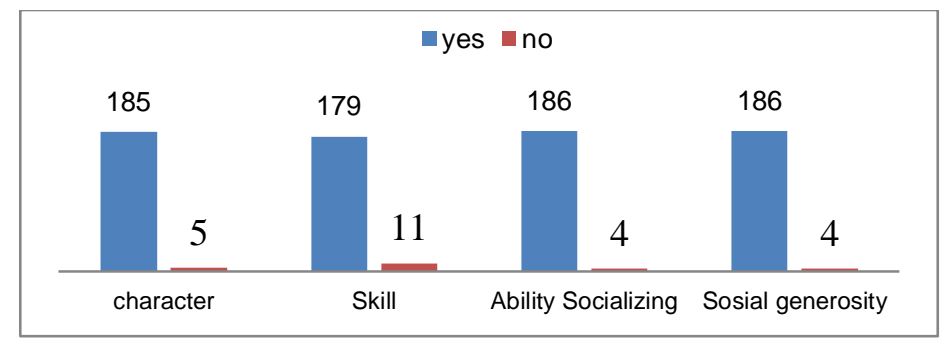

Figure 9.

Coaching Influence on the Development of Character, Skill, Ability Socializing, and Social Generosity

\subsubsection{Creating of Independent Generation}

Coaching and mentoring Beastudi Etos program are expected to create independent generation, especially in the economic field. The results of this research demonstrate the independence of alumni Beastudi Etos shown by their ability to fulfill their needs of personal 
and family. In the earlier stages etoser is part of the family members who become dependents of their parents. However, by their ability to improve the family economic condition through education and earned today, the alumni of beneficiaries Beastudi Etos serves as the responsible of their family. Table 9 shows that the majority of respondents $(78.42 \%)$ had dependents (either children, wives, parents, or their siblings) between 1-13 persons. In fact 19 respondents have dependents 5-13 persons. Meanwhile, the 41 persons $(21.58 \%$ ) despite having no dependents, but they have been able to be independent without the expense of their parents. The source of their income is from working and scholarships earned.

Table 9.

Distribution of Respondents Number of Dependents

\begin{tabular}{|c|c|c|}
\hline \multirow{2}{*}{ Number of dependents (persons) } & \multicolumn{2}{|c|}{$\begin{array}{c}\text { Number of Respondents } \\
\text { (persons) }\end{array}$} \\
\cline { 2 - 3 } & $\mathbf{n}$ & $\%$ \\
\hline 0 & 41 & 21.58 \\
\hline 1 & 31 & 16.32 \\
\hline 2 & 49 & 25.79 \\
\hline 3 & 35 & 18.42 \\
\hline 4 & 15 & 7.89 \\
\hline 5 & 9 & 4.74 \\
\hline 6 & 5 & 2.63 \\
\hline 7 & 2 & 1.05 \\
\hline 8 & 2 & 1.05 \\
\hline 13 & 1 & 0.53 \\
\hline Total & 190 & 100.00 \\
\hline Total Respondents who have dependents & 41 & 21.58 \\
\hline Total Respondents who do not have dependents & 149 & 78.42 \\
\hline
\end{tabular}

Currently, almost all respondents would be financially independent by working or getting a scholarship, so it no longer depends on their family. Based on financial independence, respondents were divided into 3 groups. The first group is they had income that totals 169 respondents $(88.94 \%)$. In most respondents (30 people) have incomes between Rp3,000,000.00-Rp4,000,000.00. 20 respondents had income between Rp4,000,000.00 Rp5,000,000.00 and 18 respondents have income more than Rp7,000,000.00. 
The second group is they do not get income because it was on going in university but they get tuition and living expenses of the scholarship. This group are 15 respondents $(7.89 \%)$ they are students who are S1 (9 persons) and being S2 (6 persons). The scholarship comes from sources inside and outside the country, including BPKLN Scholarship (for Tuition fee in Indonesia), NPUST Scholarship (for Tuition fee in Taiwan), Brain Korea (BK) scholarship 21 Scholarship Program, scholarship IMHERE (Indonesia Managing Higher Education for Relevance and Efficiency), the Japanese Government scholarship (MEX), Karya Salemba Empat Program XL Future Leaders Scholarship scholarship work Salemba Four XL Future Leaders scholarship Program, scholarship of Higher Education, and others.

And the third group is they do not earn 6 respondents (3.16\%), they are who work as housewives and also on going in university but do not get a scholarship. The group is gaining tuition from parents and from personal savings collected when they are still gaining a scholarship from Beastudi Etos. Meanwhile, from six respondents, there are two respondents who work as housewives so they get a cost from their husband.

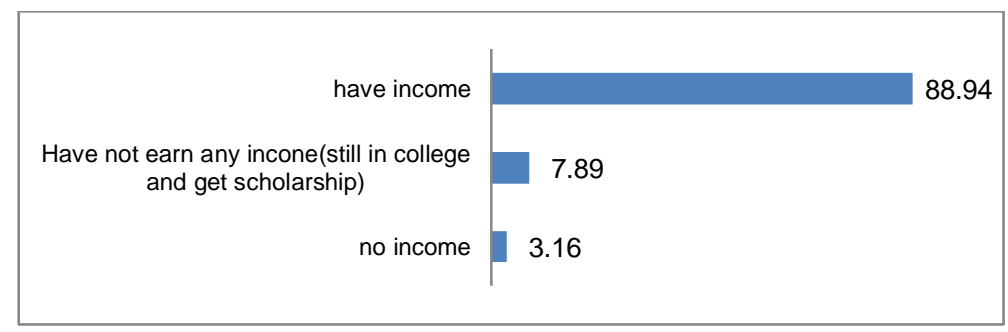

Figure 10.

Distribution of Respondents by Financial Independence (\%)

Based on Figure 10 and Table 10 it can be concluded that most of the beneficiaries of alumni Beastudi Etos has had a good financial independence by working, self-employed and obtained a scholarship before they graduate education S1. This result is consistent with the results of the research Maidiyanti (2013) that 78\% etoser have independent economic activity. Economic activities include teaching lesson course, teaching private, trade, and manager of the event organizer. Besides, do the independent economic activity, etoser has 
awareness to save earn. This is reflected in the results which showed that $51.2 \%$ of respondents said that save their earn more than 3 times in a semester, $24.4 \%$ save $2-3$ times in one semester, and a $24.4 \%$ save less than 2 times in one semester.

Table 10.

Income Level of Respondents

\begin{tabular}{|c|c|c|c|c|c|c|c|}
\hline & \multicolumn{6}{|c|}{ Education Level (People) } & \multicolumn{2}{c|}{ Total } \\
\cline { 2 - 8 } Income (Rp) & $\begin{array}{c}\text { Bachelor/ } \\
\text { S1 (On } \\
\text { progress) }\end{array}$ & $\begin{array}{c}\text { Bachelor } \\
\text { Graduates }\end{array}$ & $\begin{array}{c}\text { Master/ } \\
\text { S2 (on } \\
\text { progress) }\end{array}$ & $\begin{array}{c}\text { Master } \\
\text { Graduates }\end{array}$ & $\begin{array}{c}\text { Doctoral/ } \\
\text { S3 (on } \\
\text { progress) }\end{array}$ & $\mathbf{n}$ & $\%$ \\
\hline $\begin{array}{c}\text { Don't have any } \\
\text { income (House } \\
\text { wives; S1-in } \\
\text { process and } \\
\text { unemployed) }\end{array}$ & 4 & 2 & 0 & 0 & 0 & 6 & 3.16 \\
\hline $\begin{array}{c}\text { Has not earn } \\
\text { any income } \\
\text { (Still in } \\
\text { university and } \\
\text { receive } \\
\text { scholarship) }\end{array}$ & 9 & 0 & 6 & 0 & 0 & 15 & 7.89 \\
\hline$<1,000,000$ & 15 & 12 & 1 & 0 & 0 & 28 & 14.74 \\
\hline $\begin{array}{c}1,000,000- \\
2,000,000\end{array}$ & 3 & 18 & 5 & 0 & 1 & 27 & 14.21 \\
\hline $\begin{array}{c}2,000,000- \\
3,000,000\end{array}$ & 3 & 18 & 1 & 3 & 1 & 26 & 13.68 \\
\hline $\begin{array}{c}3,000,000- \\
4,000,000\end{array}$ & 0 & 28 & 1 & 1 & 0 & 30 & 15.79 \\
\hline $\begin{array}{c}4,000,000- \\
5,000,000\end{array}$ & 1 & 17 & 1 & 1 & 0 & 20 & 10.53 \\
\hline $\begin{array}{c}5,000,000- \\
7,000,000\end{array}$ & 0 & 20 & 0 & 0 & 0 & 20 & 10.53 \\
\hline$>7,000,000$ & 0 & 14 & 3 & 0 & 1 & 18 & 9.47 \\
\hline Total & 35 & 129 & 18 & 5 & 3 & 190 & 100 \\
\hline
\end{tabular}

By the very nature of human/households have a tendency to stay alive in order to develop their talents and social life. As a consequence they have to fulfill their needs (consumption), both food and non-food in order to live worthy of dignity as the members of society. Therefore, the value of an item is determined by the ability to fulfill the needs of people/households, while the number of needs determined by the scale of need and also by income (Esmawati, 2005).

Table 12 shows that the respondents' perceptions of the adequacy of income to fulfill the needs/family economy. The majority 
of respondents (109 persons) said that the current earned is sufficient for the family economic needs. The Income which is get either from work, partner, or scholarships are allocated for subsistence needs, university tuition, help to finance other family member, and saving. In the group that 'no income' is two of the respondents who said that the income earned sufficient, they are respondents who work as housewives. It means their husband income has been sufficient to fulfill family economy.

Meanwhile, there are 81 respondents $(42.6 \%)$ who felt that there is not sufficient income so that they have a spirit and a strong desire to get a better job. Most of respondents felt that current income is not sufficient they had incomes under Rp1,000,000.00. They are students S1 Fresh Graduation and working as freelance. They say that the income only sufficient for extra tuition and daily needs, so it has not been able to save money and help the parents.

Table 11.

Respondents Perception of the Adequacy of Income

\begin{tabular}{|c|c|c|c|c|}
\hline \multirow{2}{*}{ Income Level } & \multicolumn{4}{|c|}{ Income Adequacy } \\
\cline { 2 - 5 } & $\begin{array}{c}\text { Not } \\
\text { sufficient }\end{array}$ & Sufficient & \multicolumn{2}{|c|}{ Total } \\
\cline { 2 - 5 } & $\mathbf{n}$ & $\mathbf{n}$ & $\mathbf{n}$ & $\%$ \\
\hline $\begin{array}{c}\text { Don't have any income (House wives; } \\
\text { S1-in process and unemployed) }\end{array}$ & 4 & 2 & 6 & 3.2 \\
\hline $\begin{array}{c}\text { Has not earn any income (Still in } \\
\text { university and receive scholarship) }\end{array}$ & 10 & 5 & 15 & 7.9 \\
\hline$<1,000,000$ & 28 & 0 & 28 & 14.7 \\
\hline $1,000,000-2,000,000$ & 17 & 10 & 27 & 14.2 \\
\hline $2,000,000-3,000,000$ & 10 & 16 & 26 & 13.7 \\
\hline $3,000,000-4,000,000$ & 4 & 26 & 30 & 15.8 \\
\hline $4,000,000-5,000,000$ & 4 & 16 & 20 & 10.5 \\
\hline $5,000,000-7,000,000$ & 4 & 16 & 20 & 10.5 \\
\hline$>7,000,000$ & 0 & 18 & 18 & 9.5 \\
\hline Total & 81 & 109 & 190 & 100.0 \\
\hline
\end{tabular}

\section{CONCLUSION AND RECOMMENDATION}

\subsection{Conclusion}

The Etoser age who were respondents in this research ranged from 20-34 years or in early adult period. Most of etoser are in the age 
range between 20-24 years (96 persons). Male Respondents are (98 persons) in this research more than female respondents (92 persons). Most of the alumni who respondents in the research were from the academic year 2009 they are 52 persons.

The effectiveness of Zakat funding through Beastudi Etos to break the cycles of poverty carried out in two ways, namely (1) providing of tuition and living expenses to increase educational scholarships and (2) providing coaching and mentoring to improve the ability to obtain the changes income their families. In education, there are 816 beneficiariess of alumni who have completed their education at S1 to S3. This research found that respondents who have education SI were 164 persons, S2 were 23 persons, and S3 were 3 persons with a variety of achievements both academic and non-academic. Most respondents unmarried status (137 persons), 53 persons are married with a partner who educated S1 (32 persons). It means that education of etoser partner positively correlated with education. The higher someone education, so the higher their education partner. If the couple of etoser' education is higher then family economic life in the future will be better than their previous family economy. Thus, indirectly the cycle of poverty in the third generation will be disconnected.

Meanwhile, in economic terms, most of respondents (88.94\%) already have income (30 persons) of respondents had income between $\mathrm{Rp} 3,000,000.00-\mathrm{Rp} 4 ., 000,000.00,20$ respondents get earn between $\mathrm{Rp} 4,000,000.00-\mathrm{Rp} 5,000,000.00$, and 18 respondents has an income above Rp7,000,000.00. It seen from entrepreneurship activity as ways to reduce unemployment, as many as 38 respondents (20\%) have activity as an entrepreneur. Distribution of their income is between Rp1,000,000.00 to Rp750 million per month and employee is between 1-8 persons.

The effectiveness of the Zakat Funding through Beastudi Etos program in creating the excellent and independent generation are also seen on 3 things:

1. The generation that is able to compete in the working world. This is shown by period to get a job. More than half of the respondents $(61.29 \%)$ get a job with pure competence through the stages of the test. Most of the respondents $(56.80 \%)$ had 
worked before graduation. Ease of respondents in employment is influenced by coaching and mentoring gained during Beastudi Etos program. This is proved by the results of research showing that most of respondents (124 persons) stated that the coaching and mentoring programs can improve their knowledge in facing the working world. 21 respondents said that it is good enough. Meanwhile, $65.26 \%$ of respondents said that coaching and mentoring Beastudi Etos program obtained relevant with the requirements of the working world, $22.11 \%$ of respondents answered very relevant. The results also showed that $77.42 \%$ of respondents got a good assessment from their partner work. $20.97 \%$ got a very good assessment;

2. The excellent generation in knowledge, skill, and character. In general, the results of this research also showed that coaching and mentoring that had been given effect on the character (97.4\% of respondents), skill (94.2\% of respondents), social skill (97.9\% of respondents), and social generosity $(97.9 \%$ of respondents);

3. Financially independent generation. The independence of alumni Beastudi Etos is shown by their ability to fulfill the needs of personal and family. Most of the respondents $(78.42 \%)$ had dependents (children, wives, parents, or their siblings) between 113 persons. In fact 19 respondents have dependents 5-13 persons. Meanwhile, 41 respondents $(21.58 \%$ ) despite having no dependents, but they have been able to be independent without the expense of their parents.

\subsection{Recommendation}

The results showed that the distribution of Zakat funding through Beastudi etos program is one of effective way to break the cycle of poverty and create the excellent and independent generation. In accordance with the results of this research, the improving of education is positively correlated with economic development, and improving the competence of human resources will improve the next generation. Thus, the recommendations are made in this research are:

1. For program manager. Tools should be made clearer on the monitoring and evaluation of the beneficiaries. Program manager 
should also have design clearer competence achievement. In general, in order to optimize the achievement of student competencies, necessary policies, focus, creativity, initiative and support facilities. More specifically, the need for more intensive coaching and mentoring for etoser to improve their competence in English, writing and mastery of technology. In addition, program manager should do better management to the beneficiariess alumin, particularly related to the data base due to incomplete alumni data makes it difficult to access the alumni.

2. For zakat institution. The distribution of zakat is quite effective in the presence of such empowerment programs and funding, particularly in terms of education. Therefore Beastudi Etos program is quite suitable as reference material to break the cycles of poverty.

3. For Higher Education Institutions. It should be opened the opportunities for students from disadvantaged communities to get higher education in order to break the gap and expand the distribution of welfare society. It should be more attention on achievement of student competencies, not only focus on improving IPK. Placement of new students in the dormitory students needs to be equipped with coaching and mentoring to improve the competence of student attitudes. A variety of student activities should be supported to improve the competence of students, especially skills.

4. To the manager of scholarships, the funding should not be an sich, but need to be added a variety of appropriate training to improve the competency of students.

5. For further research development, research can be conducted to examine the impact of the beneficiaries of alumni Beastudi Etos in the future. It should be also done extensive research on the effectiveness of the program through regression and correlation method with a more complete instrument and more respondents. 


\section{REFERENCES}

Badan Pusat Statistik. (2013). Jumlah pengangguran Indonesia. Retrieved March 6, 2014, from di http://bps.go.id

Badan Pusat Statistik. (2012). Data kemiskinan Indonesia. Retrieved March 15, 2014, from http://www.bps.go.id/brs_file/kemiskinan _ 02jan13.pdf

Badan Pusat Statistik. (2012). Susenas: Angka partisipasi perguruan tinggi 2012. Retrieved M arch 8, 2014, from di http://bps.go.id

Beasiswa Djarum (n.d.). Tentang program beasiswa Beswan Djarum. Retrieved February 20, 2014, from http://djarumbeasiswaplus. org/ beswandjarum

Beastudi Etos. (2011). Standar operasional prosedur. Bogor: Author.

Beastudi Etos. (2009). Profil Beastudi Etos. Bogor: Lembaga Pengembangan Insani.

Beastudi Indonesia. (n.d.). Program Beastudi Etos. Retrieved Mar 14, 2014 from http://bestudiindonesia.net

Bkn.go.id. (n.d.). Retrieved from http://www.bkn.go.id/penelitian/ buku\% 20penelitian\% 202004/buku\% 20Peny.\% 20Ped.\% 20Pen g.\% 20Kompetensi\% 20PNS/bab\% 20ii.htm

Boyle, P. G. (1981). Planning better programs. Wisconsin: Mc Graw Hill Book Company.

Centerpoint.co.id. (n.d.). Retrieved from http://centerpoint.co.id/onestop-it-solutions/tutorial/saint-dan-iptek/definisi-kompetensi. html

Departemen Keuangan Republik Indonesia. (n.d.). Anggaran pendapatan dan belanja negara tahun 2013. Retrieved February 19, 2014, from http:// www.anggaran.depkeu.go.id

Direktorat Jenderal Pendidikan Tinggi Kementerian Pendidikan dan Kebudayaan. (2011). Beasiswa dan bantuan pendidikan. Retrieved February 21, 2014, from http://www.perpustakaan.kemdik nas.go.id 
Esmawati, F. (2005). Analisis konsumsi rumah tangga di Kabupaten Brebes tahun 2004 (skripsi). Fakultas Ekonomi Universitas Sebelas Maret, Surakarta.

Farida, D. (2012). Karakteristik perkembangan usia dewasa. Retrieved March 13, 2014, from http://dewifarida-pendidikan.blogspot.co. id/2012/01/karakteristik-perkembangan-usia-dewasa.html

Fukuyama, F. (1995). Trust, the social virtues and the creation of prosperity. London: Hamish Hamilton.

Hariyanto, B. (2004). Direktori beasiswa pendidikan dasar, menengah, dan tinggi dalam dan luar negeri tahun 2004-2005. Jakarta: www.rajaraja.com

Heikkila, E.J. (1999). From HDI to hdi: A case study of local planning and human development in Indonesia. Regional Development Studies, 5, 41-62.

Hurlock, E. B. (1968). Developmental psychology (3 ${ }^{\text {rd }}$ ed). New York: McGraw-Hill.

Ife, J. (1995). Community development creating community alternatives-vision, analysis and practice. M elbourne: Longman.

IPM Indonesia 2013. (n.d.). Kompasiana. Retrieved March 8, 2014, from http://ekonomi.kompasiana.com/bisnis/2013/06/30/ipmindonesia-2013-sudah-di-level-mana-573409.html

Jumlah Pengusaha Indonesia. (2013). Sindonews. Retrieved M arch 10, 2014, from http://ekbis.sindonews.com/read/2013/09/19/34/ 785269/jumlah-pengusaha-di-indonesia-hanya-1-25

Karya Salemba Empat. (n.d.). Program beasiswa. Retrieved February 20, 2014, from http://www.karyasalemba4.org/node/74

Lord, J. \& Hutchison, P. (1993). The process of empowerment: implication for theory and practice. Canadian Journal of Community Mental Health, 12(1), Spring 1993, 5-22. Retrieved Juni 3, 2013, from http://www.johnlord.net/web_documents/process_ of_empowerment.pdf.

Meidiyanti. (2013). Efektifitas program beasiswa untuk meningkatkan prestasi mahasiswa (Kasus pada mahasiswa penerima beasiswa 
beastudi Etos di Jabodetabek) (tesis). Pascasarjana Fakultas Ekologi Manusia, Institut Pertanian Bogor, Bogor.

Notoatmodjo, S. (2003). Metodologi penelitian kesehatan (cetakan ketiga). Jakarta: Rineka Cipta.

Penduduk Indonesia Diperkirakan 250 Juta Jiwa. (n.d.). Republika online. Retrieved March 14, 2014, from http://www.republika. co.id/berita/nasional/umum/13/07/17/mq2oy6-2013-pendudukindonesia-diperkirakan-250-juta-jiwa

Prijono, S., \& Pranarka, A. M. W. (1996). Pemberdayaan: Konsep, kebijakan dan implementasi. Jakarta: Centre for Strategic and International Studies.

Pusat Data dan Analisis Tempo. (n.d.). Peringkat 10 besar perguruan tinggi tahun 2007. Retrieved April 8, 2011, from http://tempo.co

Rogers, E. M. (2003). Diffusion of innovation $\left(5^{\text {th }}\right.$ ed.). New York: Free Press.

Santrock, J. W. (2008). Adolescence $\left(12^{\text {th }}\right.$ ed.). New York: McGraw-Hill Higher Education.

Sekretariat Kabinet Republik Indonesia. (n.d.). Anggaran pendidikan 2013. Retrieved March 10, 2014, from http://setkab.go.id/ berita-5407-anggaran-pendidikan-2013-rp-331-triliun-rp-234triliun-untuk-bos-rp-431-triliun-untuk-tunjangan-guru.html

Sirait, J. (2006). Memahami aspek-aspek pengelolaan sumber daya manusia dalam organisasi. Jakarta: Grasindo.

Suharto, E. (2005). Membangun masyarakat memberdayakan rakyat. Bandung: Reflika Aditama.

Sudjana, N. (2000). Dasar-dasar proses belajar mengajar. Bandung: Sinar Baru Algasindo.

Tarigan, S. (2006). Pengaruh tingkat pendidikan terhadap tingkat pendapatan perbandingan antara empat hasil penelitian. Jurnal Wawasan, Volume 11, Nomor 3. Retrieved March 12, 2014, from http://repository.usu.ac.id/bitstream/123456789/16004/1/ was-feb2006-\% 20(3).pdf 
Tingkat Kriminalitas 2013. (n.d.). Republika online. Retrieved March 11, 2014, from http://www.republika.co.id/berita/nasional/ hukum/13/12/27/mygtns-kapolri-klaim-kriminalitas-2013menurun

Udiutomo, P. (2011). Pengaruh program pembinaan dan pendampingan terhadap peningkatan kompetensi mahasiswa (Studi kasus: Beastudi Etos Dompet Dhuafa). Jurnal Pendidikan Dompet Dhufa, Edisi l, 2011.

Udiutomo, P. (2011). Analisa tingkat kepuasan penerima beastudi Etos terhadap layanan program tahun 2011. Jurnal Pendidikan Dompet Dhufa, Edisi l, 2011.

Universitas Hasanuddin. (n.d.). Kemendikbud: Tahun 2013 lancarkan pendidikan universal. Retrieved March 12, 2014, from http://unhas.ac.id.

Universitas Indonesia. (n.d.). Kompetensi yang dibutuhkan dalam dunia kerja. Retrieved 2014 March 11, 2014, from http://staff. ui.ac.id/system/files/users/asyafiq/publication/kompetensiyangdib utuhkandalamduniakerja.pdf

Universitas Padjajaran. (n.d.). Peringkat daya saing global indonesia pada tahun 2013 dalam World Economic Forum (WEF). Retrieved March 10, 2014, from http://www.unpad.ac.id.

World Bank. (2011). Poverty line. Retrieved Mar 3, 2014, from http://www.worldbank.org

World Bank. (2013). Kemiskinan perkotaan dan ulasan program. Retrieved March 13, 2014, from http://www.worldbank.org 
228 Journal of Islamic Monetary Economics and Finance, Vol. 1, No.2, February 2016

This page is intentionally left blank 